\title{
FILOZOFIA PRZYRODY W ALCHEMII. ZARYS ZWIĄZKÓW'
}

\begin{abstract}
Streszczenie. Celem moich rozważań jest przedstawienie związków pomiędzy dociekaniami filozofów przyrody a rozwojem tradycji alchemicznej. Odwołam się do wybranych koncepcji ukształtowanych w dziejach alchemii. Będę argumentował na rzecz tezy, że dociekania alchemików przybierały postać rozbudowanych systemów tworzących koherentne obrazy świata przyrody, które implikowały określone typy filozofii przyrody.
\end{abstract}

Słowa kluczowe: filozofia przyrody; alchemia; obraz świata

1. Wstęp. 2. Wielowymiarowość alchemii. 3. Filozoficzne sposoby reflektowania nad przyrodą. 4. Filozoficzne obrazy świata przyrody w alchemii. 4.1. Nurt hermetyczno-ezoteryczny. 4.2. Nurt empiryczno-egzoteryczny. 4.3. Dualizm alchemii Paracelsusa. 5. Podsumowanie.

\section{WSTĘP}

Filozofia przyrody i alchemia są przedmiotem ludzkiego zainteresowania równie długo. Celem moich rozważań jest przedstawienie związków pomiędzy dociekaniami filozofów przyrody a rozwojem tradycji alchemicznej. $Z$ racji ograniczeń nakładanych przez formę artykułu nie mogę szczegółowo prześledzić dziejów wskazanego powinowactwa. Jestem zmuszony dokonać syntezy, która pociąga za sobą konieczność nie tylko pominięcia skądinąd ważnych składowych obu tradycji, ale przede wszystkim dokonania szeregu uproszczeń. Odwołam się tylko do wybranych koncepcji kultury alchemicznej. Dzięki temu uzyskam możliwości uchwycenia związków filozofii przyrody i alchemii w szerokiej perspektywie. Będę argumentował na rzecz tezy, że dociekania alchemików przybierały postać

1 Ostatnia moja rozmowa z ks. prof. Grzegorzem Bugajakiem dotyczyła związków filozofii i alchemii. Tekst ten poświęcam Jego pamięci. 
rozbudowanych systemów, tworzących koherentne obrazy świata przyrody, które implikowały określone typy filozofii przyrody.

\section{WIELOWYMIAROWOŚĆ ALCHEMII}

Tradycja i praktyka alchemiczna jest jednym z najbardziej nieuchwytnych fenomenów kultury. Parafrazując słowa Mistrza Eckharta, można stwierdzić: alchemia jest bezimienna. Idąc tropem wskazanym przez niemieckiego mistyka, łatwiej jest formułować negatywne twierdzenia o naturze alchemii niż pozytywne. Początki działalności alchemicznej giną w mrokach dziejów, a jej korzenie sięgają głębiej, niż znane nam ślady jej obecności w starożytnej Babilonii, Egipcie i Grecji. „Zachodni alchemik doprowadza do końca ostatni etap prastarego programu rozpoczętego przez homo faber w dniu, gdy podjął on dzieło przekształcania natury - natury zawierającej w sobie sacrum i potencjalną hierofanię. Idea alchemicznej transmutacji jest cudownym ukoronowaniem wiary w możliwość zmieniania natury poprzez ludzką pracę"2. Do momentu rozpoczęcia się w XVII wieku wielkiej rewolucji naukowej dociekania alchemików były krytykowane, ale mimo wszystko akceptowane, także przez luminarzy nowożytnej nauki. Powszechnie znane jest zainteresowanie alchemią, żywione między innymi przez Roberta Boyle’a i Izaaka Newtona ${ }^{3}$. Jednak powstanie nowożytnego paradygmatu poznania naukowego przesądziło o odrzuceniu i instancjonalnym uznaniu alchemii za działalność pseudonaukową. Alchemia została wyrzucona poza ramy

2 M. Eliade, Kowale i alchemicy, tłum. z ang. A. Leader, Wydawnictwo Aletheia, Warszawa 2007, 187-188

3 L Principe, The Aspiring Adept: Robert Boyle and his Alchemical Quest, Princeton University Press, Princeton 1998; W.R. Newman, The Alchemical Sources of Robert Boyle's Corpuscular Philosophy, Annals of Science 53(1996)6, 567-585; B.J.T. Dobbs, The Foundations of Newton's Alchemy: Or, „The Hunting of the Greene Lyon”, Cambridge University Press, Cambridge 1975; W. Newman, Newton the Alchemist: Science, Enigma, and the Quest for Nature's „Secret Fire”, Princeton University Press, Princeton - Oxford 2019. 
racjonalnego myślenia i tym samym usunięta $z$ akademii, zeszła „do podziemia”, dając początek różnorakim nurtom ezoterycznych poszukiwań. Biorąc pod uwage „długie trwanie” tej tradycji, niezmiernie trudno wskazać składowe aktywności alchemików, które bezwzględnie zawsze określały istotę ich działalności.

Badacze, podejmując próbę zdefiniowania alchemii, zwykle starają się podkreślać jej synkretyczny charakter. Dla przykładu Frank Sherwood Taylor stwierdził: „Alchemia nie jest łatwa do zdefiniowania. Niektórzy chcieliby zawęzić jej znaczenie do »transmutacji metali«; inni pragną włączyć w jej zakres wszystko, co odnosi się do egzaltacji i regeneracji czy to metali, czy ludzkiego umysłu. Alchemia nie jest tożsama ani z mistycyzmem, ani z metalurgią. Jeden $\mathrm{z}$ najwcześniejszych tekstów alchemicznych, Physika kai mystika Demokryta (ok. 100 r.n.e), najkrócej wyraża swoim tytułem naturę opisanej w niej sztuki, którą można zdefiniować następująco: sztuka pozornie odnosząca się do transmutacji metali, a opisywana za pomocą terminologii jednocześnie fizycznej i mistycznej”" Z kolei Michael Pereira zauważa: „Alchemia jest poszukiwaniem czynnika materialnej doskonałości, wytworzonego poprzez twórczą aktywność (opus), w której człowiek i natura współpracują. Występuje w wielu kulturach (Chin, Indii, Islamu; w świecie łacińskim od czasów hellenistycznych) w różnych formach: dążąc do produkcji złota; udoskonalenia substancji podstawowych; stworzenia eliksiru przedłużającego życie, a nawet dającego nieśmiertelność. Ze względu na swój cel, aktywność alchemików jest zawsze ściśle związane z religijną doktryną odkupienia, która obecna jest w każdej cywilizacji, w której alchemia jest stosowana"

4 F. Sherwood Taylor, The Origins of Greek Alchemy, Ambix 1(1937)1, 30. (Chodzi o tekst alchemiczny błędnie przypisywany Demokrytowi (pseudo-Demokrytowi) Physika kai mystika - przyp. red.)

5 M. Pereira, Alchemy, w: Routledge Encyclopedia of Philosophy, red. E. Craig, Routledge, London - New York 1988, 155. 
W świetle przytoczonych powyżej prób scharakteryzowania alchemii - tylko dwóch spośród licznych obecnych w literaturze przedmiotu - można stwierdzić, że sztuka alchemiczna uprawiana była w różnorakich osnowach: geograficznych, historycznych, kulturowych, religijnych, filozoficznych. Wielość wymienionych powyżej kontekstów pokazuje, że z perspektywy współczesnej humanistyki „kultura alchemiczna” musi być dyskutowana jako aktywność wielowymiarowa. Tym samym nie sposób, bez poczucia swoistego dysonansu, zredukować aktywności alchemików do - w jakiś sposób rozumianej-esencji. Ponadto, obraz alchemii komplikuje się, kiedy odwołamy się do twierdzeń na temat alchemii, które formułowali ją praktykujący. Rafał Prinke podkreśla ten fakt: „Rozumienie słowa "alchemia« zmieniało się nie tylko w różnych epokach, ale często współcześni sobie autorzy używali tego terminu w bardzo odmiennych znaczeniach"6.

Dostrzegana przez Prinke polisemia w użyciu terminu alchemia wynikała między innymi z tego, że działalność alchemików miała charakter dwuwymiarowy: egzoteryczny i ezoteryczny ${ }^{7}$. Roger Bacon w Opus Tertium (1267) składnik egzoteryczny określał jako praktykę materialną (alkimia operativa et practica), a komponent ezoteryczny (alkimia speculativa) utożsamiał z refleksją duchową i mistyczną ${ }^{8}$. $Z$ tej perspektywy w tradycji alchemicznej można wyodrębniać dociekania, które w większym stopniu prowadzone były w sposób, który ze współczesnej perspektywy można określić jako protolaboratoryjny9.

6 R.T. Prinke, Zwodniczy ogród błędów. Piśmiennictwo alchemiczne do końca XVIII wieku, Wydawnictwo PAN, Warszawa 2014, 19.

7 W.H. Brock, Historia chemii, tłum. z ang. J. Kurłowicz, Prószyński i s-ka, Warszawa 1999, 16-17.

8 G.F. Călian, Alkimia operativa and alkimia speculativa. Some Modern Controversies on the Historiography of Alchemy, w: Annual of Medieval studies at CEU, vol. 16, red. J.A. Rasson, K. Szende, Central European University Budapest, Budapest 2010, 178.

9 R. Kazibut, Pseudolaboratorium - protolaboratorium - nauki laboratoryjne. Zasada intersubiektywnej powtarzalności i odtwarzalności jako kryterium demarkacji, Studia Philosophica Wratislaviensia 7(2012)4, 105-121. 
Analogicznie można wskazać koncepcje alchemiczne, których autorzy zainteresowani byli tylko dociekaniami o charakterze duchowym, tym samym marginalizując wymiar materialny. Badacze dziejów alchemii przekonują, że rozdzielanie składnika ezoterycznego i egzoterycznego aktywności alchemicznej ma uzasadnienie co najwyżej analityczne. W świetle materiału historycznego działalność alchemików była przede wszystkim konglomeratem praktyki i spekulacji1 ${ }^{10}$.

\section{FILOZOFICZNE SPOSOBY REFLEKTOWANIA NAD PRZYRODĄ}

Michał Heller zaproponował typologię filozoficznej refleksji nad przyrodą. Przyjął w niej podział, w którym status poznawczy danej koncepcji, ukształtowanej w dziejach filozofii przyrody, jest oceniany przez pryzmat związków danej koncepcji z osiągnięciami nauk przyrodniczych. Tylko filozofia przyrody, która „przylega do nauki”, tzn. budowana jest na podstawie ustaleń dokonanych przez przyrodoznawców, może dostarczać wiedzę o świecie, a tym samym być wartościowa poznawczo. Jednocześnie taka filozofia przyrody musi być konstruowana zgodnie $z$ regułami metodologicznymi ustalonymi na gruncie filozofii nauki ${ }^{11}$. Zaproponowaną przez Hellera perspektywę oceny wartości koncepcji z zakresu filozofii przyrody można określić jako podejście scjentystyczne. Znaczenie ma tylko taka filozofia przyrody, którą na płaszczyźnie epistemologicznej, ontologicznej i metodologicznej można powiązać $\mathrm{z}$ ustaleniami nauk przyrodniczych. Kwestia, na ile uprawiana w ten sposób filozofia przyrody pozostaje autonomiczna względem przyrodoznawstwa, a tym samym bada obszary nie eksplorowane przez nauki empiryczne, jest zagadnieniem, które pozostawiam bez rozstrzygnięcia. Zaakceptowanie kryterium

10 Zob. R. Halleux, Les texst alchimiques, (Typologie des Sources du Moyen Age Occidental, Fasc. 32), Brepols, Turnhout 1979, 49.

11 M. Heller, Czy istnieje autentyczna filozofia przyrody?, Studia Philosophiae Christianae 23(1987)1, 8-10. 
Hellera pociąga za sobą następujące konsekwencje: po pierwsze, każda refleksja filozoficzna nad przyrodą, która poszukuje legitymizacji w innych źródłach niż nauki przyrodnicze nie ma wartości poznawczej; po drugie, filozofia przyrody w znacznym stopniu staje się filozoficzną refleksją nad dokonaniami przyrodoznawstwa; po trzecie, o wartościowej poznawczo filozofii przyrody można mówić tylko od momentu ukształtowania się nowożytnego paradygmatu poznania naukowego ${ }^{12}$. Przyjęcie kryterium Hellera wyklucza możliwość uznania refleksji alchemicznej jako dostarczającej wartościowej wiedzy o świecie przyrody.

Bardzo powszechne jest przekonanie, że alchemia to paradygmatyczny przykład działalności pseudonaukowej. Jednak prowadzona na ten temat $w$ literaturze przedmiotu dyskusja pokazuje, że alchemicy w wielu aspektach swojej aktywności postępowali w sposób racjonalny. Badacze argumentują, że tradycję alchemiczną należy identyfikować jako protonaukową działalność poznawcząa ${ }^{13}$. Zgadzając się z tym ujęciem relacji pomiędzy alchemią a nauką, można uznać, że w dziejach ludzkości alchemia odegrała podobną funkcję, jak np. jońska filozofia przyrody. Aby uzasadnić ten pogląd wykorzystam zaproponowaną przez Zygmunta Hajduka systematyzację stylów uprawiania filozofii przyrody. Hajduk proponuje następującą typologię filozofii przyrody: „W filozofii przyrody pierwszego rzędu (PN1) źródło to jest niezależne od konstrukcji budowanych w naukach

12 Heller stwierdził, że przed powstaniem nowożytnej nauki nie ma problemu z oceną wartości poznawczej przed-nowożytnych koncepcji przyrody, gdyż de facto stanowiły etap przygotowawczy do powstania nauk przyrodniczych, były filozoficznymi i przednaukowymi epilogami powstania nauki Por. M. Heller, Czy istnieje autentyczna filozofia przyrody?, dz. cyt., 7.

13 T.H. Levere, Transforming Matter. A History of Chemistry from Alchemy to the Bucky-ball, The Johns Hopkins University Press, Baltimore - London 2001; W.R. Newman, L.M. Principe, Alchemy vs. Chemistry: The Etymological Origins of a Historiographic Mistake, Early Science Medicine 3(1998)1, 32-65; L.M. Principe, Apparatus and Reproducibility in Alchemy, w: Instruments and Experimentation in the History of Chemistry, red. F.L. Holmes, T.H. Levere, The MIT Press, Cambridge - London 2000, 55-74. 
przyrodniczych, zaś w uzasadnianiu jej tez nie odwołujemy się do wyników tych nauk, nazywa się więc uzasadnianiem bezpośrednim. Filozofia przyrody drugiego rzędu (PN2) jest oparta na aktualnych teoriach przyrodniczych genetycznie i uzasadniająco, jest więc ono (uzasadnianie) pośrednie. W filozofii przyrody typu »mieszanego« (PNM) występują obydwa rodzaje świadectw: obok wyników nauk przyrodniczych w uzasadnianiu są angażowane explicite tezy określonego stanowiska ontologicznego i epistemologicznego. Przy konstruowaniu w miarę adekwatnego obrazu korzysta się z określonych teorii naukowych i filozoficznych punktów widzenia"14. Tak jak w przypadku kryterium Hellera, również Hajduk wprowadza rozróżnienie filozofii przyrody ze względu na relację danej koncepcji do nauk przyrodniczych. Jednakże w przeciwieństwie do Hellera nie deprecjonuje wartości tych filozoficznych ujęć świata przyrody, które czerpią inspirację z innych, nie naukowych źródeł.

Ze względu na przedmiot moich rozważań proponuję modyfikację propozycji Hajduka. Przyjmuję, że typ filozofii przyrody jest wyznaczony przez epistemologiczne założenia, determinujące utrzymywany w danej koncepcji obraz świata. Źródłem przesłanek epistemologicznych może być charakter empiryczny i pozaempiryczny. Proponuję zmodyfikowany podział, w którym wyodrębniam: (1) filozoficzne obrazy świata przyrody oparte na założeniach epistemologicznych, wyprowadzonych z wiedzy pozaempirycznej; (2) filozoficzne obrazy świata przyrody oparte na założeniach epistemologicznych wyprowadzonych z wiedzy empirycznej; (3) filozoficzne obrazy świata przyrody o charakterze mieszanym, w których występują założenia epistemologiczne, wyprowadzone $z$ wiedzy empirycznej i pozaempirycznej. $Z$ tej perspektywy koncepcje alchemiczne będę mógł opisywać jako systemy założeń, w których przyjmowano i zakładano określone obrazy świata przyrody. Systemy te konstytuowane były

14 Z. Hajduk, Filozofia przyrody Isaaca Newtona, Studia Philosophiae Christianae 24(1988)2, 119. 
przez przesłanki filozoficzne formułowane na podstawie wiedzy empirycznej lub pozaempirycznej.

\section{FILOZOFICZNE OBRAZY ŚWIATA PRZYRODY W ALCHEMII}

\subsection{NURT HERMETYCZNO-EZOTERYCZNY}

Centralnym dziełem alchemicznego hermetyzmu jest zbiór starożytnych greckich tekstów, nazywany Corpus Hermeticum. Duchowość i związana z nią tajemnica wtajemniczenia w arkana alchemii była obecna we wszystkich odsłonach tradycji alchemicznej. Jednak swoiste apogeum myślenia hermetycznego przypada na XV wiek. Szczególne miejsce w bibliotece hermetyzmu znajduje Tablica Szmaragdowa - tekst przypisywany mitycznej postaci Hermesa Trismegistosa. Relacje pomiędzy tekstem Tablicy Szmaragdowej a Corpus Hermeticum są przedmiotem studiów. Badacze dopatrują się wpływu greckiego hermetyzmu na kształt tekstu, przypisywanego Trismegistosowi ${ }^{15}$. Tworzą go sentencje, których odczytanie ze współczesnej perspektywy ma charakter poetycki i metaforyczny. Jednakże musiał oddziaływać w niezwykły sposób na wyobraźnię kolejnych pokoleń alchemików, którzy czerpali z niego inspirację oraz poszukiwali wytycznych do swojej pracy. W tłumaczeniu tekst ten brzmi następująco:

„Słowa tajemnic Hermesa Trismegistosa

Prawdziwe, bez kłamstwa, pewne i najprawdziwsze.

To, co jest niżej, jest jak to, co jest wyżej, a to, co jest wyżej, jest jak to, co jest niżej, dla przeniknięcia cudów jedynej rzeczy.

I tak jak wszystkie rzeczy powstały z jednego, z myśli jednego, tak wszystkie rzeczy zostały zrodzone $\mathrm{z}$ tej jednej rzeczy, przez przystosowanie.

Ojcem jego jest Słońce, matką Księżyc; wiatr wynosił go w swym łonie; karmicielką jego jest ziemia.

15 R.T. Prinke, Zwodniczy ogród błędów..., dz. cyt., 101-102. 
Ojciec wszelkiego stworzenia całego świata jest tutaj.

Siła jego jest zupełna, jeżeli zamieni się w ziemię.

Oddzielisz ziemię od ognia, subtelne (lotne) od gęstego, z wolna, z wielką zręcznością.

Wznosi się z ziemi ku niebu i powtórnie zstępuje na ziemię i otrzymuje siłę wyższych i niższych. Tak posiądziesz chwałę całego świata. Dlatego odstąpi od ciebie wszelka ciemność.

Ta jest wszelkiej mocy potężna siła: ponieważ zwycięży wszelką rzecz subtelną i przeniknie każde ciało stałe.

Tak został stworzony świat.

Takie będą cudowne przystosowania, których sposób jest tu zawarty.

Dlatego jestem nazwany Hermesem Potrójnie-Wielkim (Hermes Trismegistos), posiadającym trzy części filozofii całego świata.

To jest zupełne, co powiedziałem o działaniu Słońca"16.

Nie trudno znaleźć w tych „natchnionych” zdaniach toposy, które odnajdujemy np. w metafizyce Platońskiej i neoplatońskiej, a także w monistycznej filozofii przyrody. „Relacja między światem niebiańskim (makrokosmosem, »to, co jest ponad «) i światem ziemskim (mikrokosmosem, »tym, co jest poniżej«) wydaje się być wystarczająco jasna. Wydaje się również, że istnieje odniesienie do monizmu (»wszystko było z jednego«), zbliżonego do znaczenia Uroborosa”17. $Z$ tego gruntu wyrasta obraz świata przyrody, w którym realizuje się całe spektrum przekonań antycznej filozofii. Natura - świat przyrody - wszechświat jawią się człowiekowi jako dynamiczna struktura o określonej z góry (w nadprzyrodzony sposób) hierarchii mocy. Dostrzegany ład przyrody wyłonił się z dynamicznej gry pomiędzy mocami, określonymi w hierarchii doskonałości. W zależności od systemu filozoficznego ten kreacyjny czynnik był ujmowany

16 Cyt. za: R. Bugaj, Hermetyzm, Zakład Narodowy im. Ossolińskich, Wrocław - Warszawa - Kraków 1991, 120.

17 L.M. Principe, The Secrets of Alchemy, The University of Chicago Press, Chicago 2013, 32. 
monistycznie i redukowany do jednej siły lub charakteryzowany jako gra pomiędzy przeciwieństwami, dokonująca się w układzie binarnym lub wieloelementowym. Pomimo tego w świecie dominuje potęga jednego czynnika, który jest uprzywilejowany w stosunku do innych ${ }^{18}$. Janusz Sytnik-Czetwertyński podkreśla panteistyczny charakter duchowości hermetyzmu. W naturze drzemie pierwotna, prastara siła, która jest przyczyną wszelakiego istnienia. Moc ta przenika cały świat, rządzi nim i jest świadomą inteligencją ${ }^{19}$.

Jeżeli można wskazać wspólny mianownik dla hermetyzmu w alchemii, to stanowi go programowa niechęć przedstawicieli tego nurtu do szeroko rozumianej filozofii arystotelesowskiej. Marsilio Ficino (1433-1499), zafascynowany myślą Hermesa Trismegistosa, łączył z nią wątki filozoficzno-teologiczne, czerpiąc z mistycyzmu filozofii platońskiej i pitagorejskiej, a na drugi plan rozważań odsuwał arystotelizm ${ }^{20}$. Bardzo wyrazistym przykładem krytyki tradycji arystotelesowskiej, dokonanej przez przedstawicieli hermetyzmu, jest atak Paracelsusa (1493-1541) na medycynę galenowską, która wyrastała wprost $\mathrm{z}$ teorii żywiołów Arystotelesa ${ }^{21}$. Odrzucenie arystotelizmu i afirmację filozoficznej perspektywy Platona uznać można za konstytutywną dla nurtu hermetyczno-ezoterycznego w alchemii. Tym samym wyrastająca $z$ tego nurtu filozofia przyrody tworzona była $\mathrm{w}$ duchu filozoficznego idealizmu. Zakładany w hermetyzmie obraz świata przyrody był ustrukturyzowany według opozycji „odkrytych" przez Platona: cielesne/niecielesne, zmysłowe/ponadzmysłowe, empiryczne/ponadempiryczne, fizyczne/ponadfizyczne. W nurcie

18 J.P. Vernant, Źródła myśli greckiej, tłum. z fr. J. Szacki, Słowo/Obraz/Terytoria, Gdańsk 1996, 122.

19 J. Sytnik-Czetwertyński, Hermetyzm w filozofii Isaaca Newtona, Kwartalnik Filozoficzny 43(2015)2, 157-158.

20 J. Monfasani, Marsilio Ficino And The Plato-Aristotle Controversy, w: Marsilio Figino: His Theology, His Philosophy, His Legacy, red. M.J.B. Allen, V. Rees, M. Davies, Brill, Leiden Boston - Köln 2002, 179-202.

21 L.N. Magner, A History of Medicine, Taylor and Francis, London - New York - Singapore 2005, 221. 
hermetyczno-ezoterycznym alchemii ukształtowano filozoficzny obrazy świata przyrody oparty na założeniach epistemologicznych, wyprowadzonych $z$ wiedzy pozaempirycznej. Dowartościowany został intelektualny wgląd $\mathrm{w}$ istotę natury-przyrody, utożsamiany $z$ doświadczeniem mistycznym i duchowym, a sama przyroda jawiła się jako depozytariuszy tajemnic nadprzyrodzonych mocy.

\subsection{NURT EMPIRYCZNO-EGZOTERYCZNY}

Podczas wielkiej rewolucji naukowej podważona została wartość poznawcza dokonań alchemików, a z czasem ich działalność uznano za wzorzec postępowania pseudonaukowego. Zrębami epistemologicznymi rodzącego się w XVII wieku nowego paradygmatu poznania naukowego były racjonalizm i empiryzm. Krytyka dorobku alchemików wyrastała z przekonania o tym, że że rezultaty ich badań nie mają empirycznego uzasadnienie. Utarło się przekonanie, że alchemicy pracowali w niesystematyczny i niechlujny sposób. Brakować im miało metodologicznej dyscypliny, a w skrajnych przypadkach w ogóle nie podejmowali działalności, która miała choćby najmniejsze znamiona aktywności doświadczalno-eksperymentalnej. Jest to opinia, która we współczesnych badaniach jest podważana. Wielu alchemików stosowało metody analityczne, które - zachowując odpowiednie proporcje - można nazywać analitycznymi technikami laboratoryjnymi. $Z$ powodzeniem używali wagi analitycznej i palnika. Warsztaty alchemików nie były tylko (a tym bardziej nie przede wszystkim) miejscami poszukiwań „kamienia filozoficznego”. Były pracowniami, w których rozwijano techniki i narzędzia, które umożliwiały otrzymywanie rezultatów badawczych, wykorzystywanych następnie przez rzemieślników: farbiarzy, garbarzy, czy jubilerów ${ }^{22}$.

22 W.R. Newman, Alchemy, Assaying, and Experiment, w: Instruments and Experimentation in the History of Chemistry, red. F.L. Holmes, T.H. Levere, The MIT Press, Cambridge - London 2000, 35-54; L.M. Principe, Apparatus and Reproducibility in Alchemy, w: Instruments 
Jeżeli uznać, że transfer wiedzy odbywał się pomiędzy alchemikami a rzemieślnikami, to należy domniemywać, że jednym i drugim zależało na tym, aby ich produkty miały jak najwyższą jakość, która była weryfikowana przez nabywcę. Tym samym prace w ramach alkimia operativa et practica - w rozumieniu Rogera Bacona - nie mogły być prowadzone w sposób chaotyczny i przypadkowy. Była to rzeczywista praktyka pojetyczna. Jej zapleczem filozoficznym - szerzej mówiąc konceptualnym - był zarówno empiryzm Arystotelesa, jak i materializm starożytnych atomistów.

Mircea Eliade pokazał, że w dziejach ludzkości alchemia i rzemiosło były silnie splecione ${ }^{23}$. Przykładem tego związku jest dokonana w kulturze islamu synteza wcześniejszej tradycji alchemicznej. W wyniku tego ukształtowana została rtęciowo-siarkowa teoria metali, która została powiązana z teorią czterech żywiołów Arystotelesa ${ }^{24}$. Postacią, która łączy alchemię arabską z łacińską, jest Jabir ibn Hayyan (721-815). Alchemik ten był jednym z największych autorytetów swojego czasu i późniejszej średniowiecznej alchemii. W Europie znany był pod zlatynizowanym imieniem Geber. Przypisuje się mu autorstwo kanonicznego dla alchemii dzieła Summa Perfectionis ${ }^{25}$. Badacze dziejów alchemii uważają, że Geber wypracował filozofię korpuskularną na bazie koncepcji Merkurego-Siarki i minima naturalia Arystotelesa ${ }^{26}$. Było to preludium do „odkrycia na nowo" starożytnego atomizmu w epoce nowożytnej. Już w 1597 roku Adreas Libavius (1555-1616) w traktacie Alchymia zawarł oparte

and Experimentation in the History of Chemistry, red. F.L. Holmes, T.H. Levere, The MIT Press, Cambridge - London 2000, 55-74.

23 M. Eliade, Kowale i alchemicy, dz. cyt.

24 R.T. Prinke, Zwodniczy ogród błędów..., dz. cyt., 100-101.

25 W.R. Newman wykazał, że autorem traktatu jest włoski franciszkanin Paul z Taranto ukrywający się pod autorytetem i pseudonimem Gebera. Zob. na ten temat: W.R. Newman, The Summa Perfectionis of the Pseudo-Geber: A Critical Edition, Translation, and Study, Brill, Leiden 1991.

26 L.M. Principe, Apparatus and Reproducibility in Alchemy, dz. cyt., 56-58. 
na wynikach oświadczeń argumenty na rzecz atomizmu ${ }^{27}$. Jednakże alchemiczny zwrot ku korpuskularnej koncepcji materii dokonać się miał za sprawą Daniela Sennerta (1572-1637). William R. Newman stwierdza: „Przyjąłem, że Daniel Sennert jest przedstawicielem kulminacyjnego punktu rozwoju korpuskularnej i eksperymentalnej tradycji w alchemii łacińskiej i wernukularnej, która trwała od około 1200 do 1700 roku"28. Sennert swoje rozważania opierał na licznych obserwacjach i opowiadał się za empiryzmem. Jego stanowisko można określić mianem eklektycznego, gdyż nawiązywał zarówno do koncepcji Merkurego-Siarki Gebera, jak i tradycji arystotelesowskiej oraz scholastycznej, a także godził się z poglądami Paracelsusa i jego koncepcją tri prima. Na bazie tego szerokiego zaplecza konceptualnego podjął próbę stworzenie korpuskularnej teorii materii. Na podstawie obserwacji procesów zachodzących na poziomie makroskopowym: parowania, erozji, kondensacji, skroplenia oraz rozumowania przez analogię, argumentował na rzecz istnienia atomów ${ }^{29}$. Senert nie poszukiwał metafizycznych wyjaśnień dla obserwowanych zjawisk, a przede wszystkim powstrzymywał się od spekulowania na temat kształtu i charakteru ruchu postulowanych przez niego korpuskuł. Uznawał, że doświadczenie empiryczne nie dostarcza podstaw do wyprowadzania wniosków na ten temat. Ten sceptycyzm i powściągliwość w formułowaniu twierdzeń na temat natury materii odnaleźć można w późniejszych rozważaniach Roberta Boyle’a, który z filozofii korpuskularnej wyprowadza nowy mechanicystyczny obraz świata przyrody. Boyle stwierdził: „Kiedy mówię o filozofii

27 W.R. Newman, Experimental corpuscular theory in Aristotelian alchemy: From Geber to Sennert, w: Late medieval and early modern corpuscular matter theories, red. Ch. Lüthy, J.E. Murdoch, W.R. Newman, Brill, Leiden 2001, 291-329.

28 W.R. Newman, Corpuscular Alchemy and the Tradition of Aristotle's Meteorology, with Special Reference to Daniel Sennert, International Studies in the Philosophy of Science 15(2001)2, 151-152.

29 Tenże, Atoms and Alchemy: Chymistry and the Experimental Origins of the Scientific Revolution, The University of Chicago Press, Chicago - London 2006, 126-127. 
korpuskularnej lub filozofii mechanistycznej, daleki jestem od epikurejskiego atomizmu"30. Związki korpuskularyzmu Boyle'owskiego $\mathrm{z}$ alchemicznymi rozważaniami są dobrze rozpoznane w literaturze przedmiotu $^{31}$. Nie ma wątpliwości, że można polemizować, na ile alchemicy byli konsekwentnie empirystami i metodologicznymi naturalistami. Relatywnie łatwo krytycznie oceniać ich wkład w rozwój technik laboratoryjnych. Jednakże w świetle przywoływanej przeze mnie literatury przedmiotu nie można twierdzić, że alchemicy nie byli zainteresowaniu badaniami empirycznymi. Kultura alchemiczna rozwijała się także na gruncie materializmu i empiryzmu. Świat przyrody skrywał dla alchemików „tajemnicę tajemnic”, ale zagadkę tę niektórzy z nich chcieli rozwiązywać nie w oparciu o doświadczenie mistyczne, ale na drodze empirycznej.

\subsection{DUALIZM ALCHEMII PARACELSUSA}

Paracelsus (1493-1531) należy do najbardziej enigmatycznych postaci tradycji alchemicznej. Paracelsjańskia antropologia filozoficzna, jego wizja miejsca człowieka w przyrodzie i relacji: człowiek - Absolut natura wiązana jest $\mathrm{z}$ nurtem hermetyzmu $\mathrm{w}$ dziejach alchemii. Jak stwierdził Walter Pagel, cecha konstytutywna spojrzenia Paracelsusa na kosmogonię, teologię, filozofię naturalną i medycynę jest związana z przyjmowanym przez niego dualizmem pomiędzy makrokosmosem a mikrokosmosem ${ }^{32}$. Alchemiczny topos, w którym opisuje się świat jako grę pomiędzy makrokosmosem a mikrokosmosem, zawarty został - w przywołanej powyżej - Tablicy Szmaragdowej.

30 R. Boyle, About the Excellency and Grounds of the Mechanical Hypothesis, w: Selected Philosophical Papers of Robert Boyle, red. M.A. Stewart, Hackett Publishing Company, Cambridge 1991, 138.

31 R.W. Newman, Boyle's debt to corpuscular alchemy, w: Robert Boyle Reconsidered, red. M. Hunter, Cambridge University Press, Cambridge 1994, 107-117.

32 W. Pagel, Paracelsus. An introduction to philosophical medicine in the era of the Renaissance, Karger, Basel 1982, 50. 
Wzorzec ten jest jednym z najstarszych wyobrażeń na temat świata przyrody, które można dostrzec $\mathrm{w}$ tradycji alchemicznej, a ponadto zajmuje centralne miejsce $\mathrm{w}$ antycznej filozofii przyrody. Jednak to Paracelsus jako pierwszy do swoich rozważań wprowadził w sposób systematyczny podział na makro- i mikroświat oraz zorganizował wokół tego założenia cały swój system ${ }^{33}$. Dla Paracelusa rozróżnienie na makroświat i mikroświat nie było tylko przeciwstawieniem sobie świata duchowego i materialnego w myśl neoplatońskiego podejścia. „Kluczowe znaczenie ma dostrzeżenie dwóch nierozerwalnie sprzężonych momentów w obrębie formacji paracelsjańskiej w jej rozwoju aż po XVII wiek, które jedynie wydają się całkowicie przeciwstawne, a nawet sprzeczne, ale mają swój początek u samego Paracelsusa: moment spirytualistyczny i moment materialistyczny" 34 .

Według filozofii przyrody, którą można przypisać Paracelsusowi, świat miał być dynamiczną strukturą, uporządkowaną wzdłuż głównej opozycji: makroświat - mikroświat. W uniwersum tym centralną rolę pełniła trójca: Merkury, Siarka i Sól, która była zasadą wszechrzeczy. Demiurg - Wielki Alchemik za pomocą jej przekształceń realizował plan stworzenia. W rozstrzygnięciu relacji pomiędzy Merkurym, Siarką i Solą tkwić miała tajemnica życia i stworzenia. Trzy elementy Paracelsusa reprezentowały składnik materialny, ponadmaterialny i duchowy całego uniwersum istnienia. Jednakże to Sól stanowić miała esencję istnienia, gdyż była czynnikiem życiodajnym. W alchemii paracelsjańskiej płaszczyzna wytwórcza, manualna, techniczna, materialna, egzoteryczna zostały ujęte w ramach filozofii chemicznej, która została połączona z witalistycznym światopoglądem. Świat składać się miał z materii i z przenikającej ją witalistycznie ujmowanej energii - Soli ${ }^{35}$. Wszystkie procesy chemiczne w świecie

33 Tamże.

34 M. Woszczek, Eliasz Nauk. Apokaliptyka, paracelsjańska mistyka przyrody i narodziny nowoczesności (część pierwsza), Praktyka Teoretyczna 19(2016)1, 139.

35 A.G. Debus, The Chemical Philosophy: Paracelsian Science and Medicine in the Sixteenth and Seventeenth Centuries, Science History Publications, New York 1977; Tenże, Chemical 
fizycznym, jak również w granicach ludzkiego ciała, były wyjaśniane w odwołaniu do oddziaływań pomiędzy elementami wspomnianej triady. Procesy naturalne, np. parowanie i opady deszczu, były dla Paracelsusa wielką kosmiczną destylacją. Bóg był wielkim mistrzem alchemii, a ziemski alchemik, pracując $\mathrm{w}$ swojej pracowni w sposób analogiczny do pracy nadprzyrodzonego demiurga, wykonywał w skali ludzkich możliwości boskie procesy wytwórcze. W akcje poietycznego działania w koncepcji Parcelsusa łączył się składnik materialny i duchowy. W świecie przyrody, opisywanym w paracelsjankiej filozofii przyrody, świat materialny przeniknięty był Boską świadomością, nadając tej wyrastającej $z$ alchemicznego namysłu filozofii przyrody nie tylko wymiar duchowy, ale i panteistyczny.

\section{PODSUMOWANIE}

Związki filozofii przyrody i alchemii są wyraźne. Były one symetryczne w tym sensie, że alchemicy sięgali do myśli filozofów przyrody, a filozofowie przyrody szukali inspiracji w tekstach alchemicznych. Podobnie współcześnie uważa się, że filozofia przyrody może być uprawiana tylko $\mathrm{w}$ ścisłym związku $\mathrm{z}$ osiągnięciami nauk przyrodniczych. W przypadku relacji pomiędzy filozofią przyrody a alchemią wzajemne przenikanie się obu tych dziedzin refleksji ludzkiej wynika z oczywistego faktu, iż podział na naukę i filozofię był dziełem nowożytności, która jednocześnie odebrała alchemii, a w dużym stopniu także filozofii, status naukowości. Bez względu na to, czy alchemicy widzieli w przyrodzie sferę, którą należy penetrować jako byt duchowy, czy też badali ją empirycznie w swoich warsztatach, zawsze ich rozważania odnosiły się do kosmosu. $Z$ tego związku filozofii przyrody i alchemii narodziła się ludzka potrzeba poznania tajemnic przyrody. Ta ciekawość poznawcza, towarzysząca

Philosophy, w: Encyclopedia of the Scientific Revolution from Copernicus to Newton, red. W. Applebaum, Garland Publishing, New York - London 2000, 214-218. 
od dawien dawna człowiekowi, została odziedziczona przez współczesnych naukowców, który również kierują swoje wysiłki w stronę rozwiązania kolejnych zagadek świata przyrody. Dociekliwość filozofujących alchemików i filozofów uprawiających alchemię jest genetyczną poprzedniczką pędu do wiedzy współczesnego człowieka.

\section{BIBLIOGRAFIA}

Boyle R., About the Excellency and Grounds of the Mechanical Hypothesis, w: Selected Philosophical Papers of Robert Boyle, red. M.A. Stewart, Hackett Publishing Company, Cambridge 1991, 138-154.

Brock W.H., Historia chemii, tłum. z ang. J. Kurłowicz, Prószyński i s-ka, Warszawa 1999.

Bugaj R., Hermetyzm, Zakład Narodowy im. Ossolińskich, Wrocław - Warszawa - Kraków 1991.

Călian G.F., Alkimia operativa and alkimia speculativa. Some Modern Controversies on the Historiography of Alchemy, w: Annual of Medieval studies at CEU, vol. 16, red. J.A. Rasson, K. Szende, Central European University Budapest, Budapest 2010, 166-190.

Debus A.G., Chemical Philosophy, w: Encyclopedia of the Scientific Revolution from Copernicus to Nerwton, red. W. Applebaum, Garland Publishing, New York London 2000, 214-218.

Debus A.G., The Chemical Philosophy: Paracelsian Science and Medicine in the Sixteenth and Seventeenth Centuries, Science History Publications, New York 1977.

Dobbs B.J.T., The Foundations of Nerwton's Alchemy: Or, "The Hunting of the Greene Lyon", Cambridge University Press, Cambridge 1975.

Eliade M., Kowale $i$ alchemicy, tłum. $\mathrm{z}$ ang. A. Leader, Wydawnictwo Aletheia, Warszawa 2007.

Hajduk Z., Filozofia przyrody Isaaca Newtona, Studia Philosophiae Christianae 24(1988)2, 115-129.

Halleux R., Les texst alchimiques, (Typologie des Sources du Moyen Age Occidental, Fasc. 32), Brepols, Turnhout 1979.

Heller M., Czy istnieje autentyczna filozofia przyrody?, Studia Philosophiae Christianae 23(1987)1, 5-20.

Kazibut R., Pseudolaboratorium - protolaboratorium - nauki laboratoryjne. Zasada intersubiektywnej powtarzalności i odtwarzalności jako kryterium demarkacji, Studia Philosophica Wratislaviensia 7(2012)4, 105-121. 
Levere T.H., Transforming Matter. A History of Chemistry from Alchemy to the Bucky-ball, The Johns Hopkins University Press, Baltimore - London 2001.

Magner L.N., A History of Medicine, Taylor and Francis, London - New York Singapore, 2005.

Monfasani J., Marsilio Ficino And The Plato-Aristotle Controversy, w: Marsilio Figino: His Theology, His Philosophy, His Legacy, red. M.J.B. Allen, V. Rees, M. Davies, Brill, Leiden - Boston - Köln 2002, 179-202.

Newman R.W., Boyle's debt to corpuscular alchemy, w: Robert Boyle Reconsidered, red. M. Hunter, University Cambridge Press, Cambridge 1994, 107-117.

Newman W.R., Alchemy, Assaying, and Experiment, w: Instruments and Experimentation in the History of Chemistry, red. F.L. Holmes, T.H. Levere, The MIT Press, Cambridge - London 2000, 35-54.

Newman W.R., Atoms and Alchemy: Chymistry and the Experimental Origins of the Scientific Revolution, The University of Chicago Press, Chicago - London 2006. Newman W.R., Corpuscular Alchemy and the Tradition of Aristotle's Meteorology, with Special Reference to Daniel Sennert, International Studies in the Philosophy of Science 15(2001)2, 151-152.

Newman W.R., Experimental corpuscular theory in Aristotelian alchemy: From Geber to Sennert, w: Late medieval and early modern corpuscular matter theories, red. Ch. Lüthy, J.E. Murdoch, W.R. Newman, Brill, Leiden 2001, 291-329.

Newman W.R., Newton the Alchemist: Science, Enigma, and the Quest for Nature's „Secret Fire”, Princeton University Press, Princeton - Oxford 2019.

Newman W.R., Principe L.M, Alchemy vs. Chemistry: The Etymological Origins of a Historiographic Mistake, Early Science Medicine 3(1998)1, 32-65.

Newman W.R., The Alchemical Sources of Robert Boyle's Corpuscular Philosophy, Annals of Science 53(1996)6, 567-585.

Newman W.R., The Summa Perfectionis of the Pseudo-Geber: A Critical Edition, Translation, and Study, Brill, Leiden 1991.

Pagel W., Paracelsus. An introduction to philosophical medicine in the era of the Renaissance, Karger, Basel 1982.

Pereira M., Alchemy, w: Routledge Encyclopedia of Philosophy, red. E. Craig, Routledge, London - New York 1988, (https://www.rep.routledge.com/articles/thematic/alchemy/v-1), [dostęp 10/2020].

Principe L.M., Apparatus and Reproducibility in Alchemy, w: Instruments and Experimentation in the History of Chemistry, red. F.L. Holmes, T.H. Levere, The MIT Press, Cambridge - London 2000, 55-74.

Principe L.M., The Secrets of Alchemy, The University of Chicago Press, Chicago 2013. 
Principe L.M., The Aspiring Adept: Robert Boyle and his Alchemical Quest, Princeton University Press, Princeton 1998.

Prinke R.T., Zwodniczy ogród błędów. Piśmiennictwo alchemiczne do końca XVIII wieku, Wydawnictwo PAN, Warszawa 2014.

Sherwood T.F., The Origins of Greek Alchemy, Ambix 1(1937)1, 30-47.

Sytnik-Czetwertyński J., Hermetyzm w filozofii Isaaca Newtona, Kwartalnik Filozoficzny 43(2015)2, 151-167.

Vernant J.P., Źródta myśli greckiej, tłum. z fr. J. Szacki, Słowo/Obraz/Terytoria, Gdańsk 1996.

Woszczek M., Eliasz Nauk. Apokaliptyka, paracelsjańska mistyka przyrody i narodziny nowoczesności (częśćpierwsza), Praktyka Teoretyczna 19(2016)1, 126-171.

\title{
PHILOSOPHY OF NATURE AND ALCHEMY. AN OUTLINE OF THEIR RELATIONSHIPS
}

\begin{abstract}
The aim of my discussion is to present the relationship between the research of natural philosophers and the development of the alchemical tradition. I refer to specific concepts formulated in the history of alchemy to argue that research in this field took the form of complex systems delineating coherent pictures of the natural world and, therefore, that alchemy presupposes certain types of natural philosophy.
\end{abstract}

Keywords: philosophy of nature; alchemy; image of the world

Radosław Kazibut

Uniwersytet im. Adama Mickiewicza w Poznaniu, Wydział Filozoficzny

(Adam Mickiewicz University in Poznań, Faculty of Philosophy, Poland)

ORCID: https://orcid.org/0000-0002-1105-1378

rkazibut@amu.edu.pl

DOI: $10.21697 /$ spch.2020.56.4.06 